\title{
Research on Technological Innovation of Listed Companies in Pearl River Delta of China
}

\author{
Yan Wu \\ Beijing Institute of Technology, Zhuhai, Guangdong, China \\ Email: wuyan_zh@163.com
}

Keywords: Pearl River Delta of China, listed company, R\&D, Patent, Income, Selective sample, Tobit model

\begin{abstract}
This paper chooses the 519 companies of the Pearl River Delta listed in China's A-share market and establishes a multivariate linear regression model with the financial data of 2017. Considering the problem of selective samples, OLS and ML methods are used to analyse the general model and Truncated Regression model respectively. The results show that gross trading income has a significant and positive impact on R\&D investment. The positive influence of R\&D in manufacturing and Information Transmission, Software and Information Technology industries are higher than that in other industries. The R\&D level of Listed Companies in Shenzhen is higher than that in other cities. The manufacturing industry has the industrial agglomeration effect of patented technology, but the transformation efficiency of $R \& D$ into patented technology is not high in the manufacturing industry. Shenzhen has the urban agglomeration effect of patented technology, but the transformation efficiency of Shenzhen R\&D into patented technology is not high; the increase of patents helps to increase gross trading income, and the impact of industrial agglomeration of patents is significant, but the urban agglomeration effect of patents is not significant.
\end{abstract}

\section{Introduction}

In recent years, Chinese government has issued a large number of government documents on technological innovation. "The Opinions on Deepening the Reform of the Scientific and Technological System and Accelerating the Construction of the National Innovation System" promulgated by the State Council in September 2012 clearly points out the opportunities and challenges faced by China's technological development. Faced with the new situation and new requirements, China's independent innovation capacity is not strong enough, and technological system and mechanism are not suited to the requirements of economic and social In the "Plan for Deepening the Reform and Implementation of the Scientific and Technological System" issued by the State Council in 2015, it is proposed that by 2020, the market-oriented mechanism of technological innovation will be more perfect, and the innovative subjects such as enterprises, scientific research institutes and universities will be full of vigor and efficient coordination. In 2016, the State Council issued "The National Innovation Driven Development Strategy Outline" to optimize the layout of regional innovation and create regional economic growth poles.

The urban agglomerations of Pearl River Delta of China include nine cities, namely Guangzhou, Shenzhen, Zhuhai, Foshan, Zhongshan, Dongguan, Huizhou, Jiangmen, Zhaoqing. This paper takes 519 A-share listed companies of Pearl River Delta of China as the research object, trying to explain some problems, such as whether the listed companies of Pearl River Delta of China will increase $R \& D$ investment with the increase of gross trading income? Will the increase in R\&D input increase the level of technology? Will patent technology increase gross trading income of PRD companies? These are our concerns. 


\section{Research on Technological Innovation of Listed Companies in Pearl River Delta of China}

\subsection{Technological Innovation of Listed Companies in Pearl River Delta}

Table 1 The Regional Distribution of Technological Innovation of Listed Companies in the Pearl River Delta of China

\begin{tabular}{|c|c|c|c|c|}
\hline City & $\begin{array}{c}\text { Number of listed } \\
\text { companies }\end{array}$ & $\begin{array}{c}\text { Number of listed } \\
\text { companies listing } \\
\text { R\& D expenditure }\end{array}$ & $\begin{array}{c}\text { Number of listed } \\
\text { companies listing } \\
\text { the original value } \\
\text { of patent } \\
\text { technology }\end{array}$ & $\begin{array}{c}\text { Number of listed } \\
\text { companies listing } \\
\text { R\& D expenditure } \\
\text { and the original } \\
\text { value of patent } \\
\text { technology }\end{array}$ \\
\hline Shenzhen & 280 & 208 & 115 & 97 \\
\hline Guangzhou & 98 & 77 & 35 & 30 \\
\hline Foshan & 36 & 30 & 10 & 7 \\
\hline Zhuhai & 28 & 22 & 16 & 13 \\
\hline Dongguan & 27 & 23 & 10 & 10 \\
\hline Zhongshan & 20 & 15 & 12 & 7 \\
\hline Jiangmen & 12 & 10 & 7 & 5 \\
\hline Huizhou & 11 & 9 & 6 & 3 \\
\hline Zhaoqing & 7 & 7 & 3 & 182 \\
\hline Total & 519 & 401 & & \\
\hline
\end{tabular}

Sources: Choice database.

Table 2 The Industry Distribution of Technological Innovation of Listed Companies in the Pearl River Delta of China

\begin{tabular}{|c|c|c|c|c|}
\hline Industry & $\begin{array}{l}\text { Number of } \\
\text { listed } \\
\text { companies }\end{array}$ & $\begin{array}{c}\text { Number of } \\
\text { listed } \\
\text { companies } \\
\text { listing R\& D } \\
\text { expenditure }\end{array}$ & $\begin{array}{l}\text { Number of } \\
\text { listed } \\
\text { companies } \\
\text { listing the } \\
\text { original } \\
\text { value of } \\
\text { patent } \\
\text { technology }\end{array}$ & $\begin{array}{l}\text { Number of } \\
\text { listed } \\
\text { companies } \\
\text { listing R\& D } \\
\text { expenditure } \\
\text { and the } \\
\text { original value } \\
\text { of patent } \\
\text { technology } \\
\end{array}$ \\
\hline Manufacturing & 337 & 300 & 163 & 148 \\
\hline $\begin{array}{c}\text { Information Transmission, Software and } \\
\text { Information Technology }\end{array}$ & 46 & 40 & 15 & 12 \\
\hline Real Estate & 25 & 5 & 1 & 0 \\
\hline Construction & 22 & 11 & 10 & 5 \\
\hline Transport, Storage and Post & 19 & 6 & 6 & 2 \\
\hline Wholesale and Retail Trades & 18 & 9 & 4 & 2 \\
\hline Leasing and Business Services & 15 & 10 & 3 & 3 \\
\hline Financial Intermediation & 11 & 0 & 0 & 0 \\
\hline $\begin{array}{c}\text { Production and Supply of Electricity, Heat, Gas } \\
\text { and Water }\end{array}$ & 10 & 6 & 4 & 3 \\
\hline Scientific Research and Technical Services & 6 & 6 & 4 & 4 \\
\hline $\begin{array}{c}\text { Management of Water Conservancy, } \\
\text { Environment and Public Facilities }\end{array}$ & 3 & 3 & 2 & 2 \\
\hline Culture, Sports and Entertainment & 2 & 0 & 1 & 0 \\
\hline Others & 2 & 2 & 1 & 1 \\
\hline Mining & 1 & 1 & 0 & 0 \\
\hline Health and Social Service & 1 & 1 & 0 & 0 \\
\hline Hotels and Catering Services & 1 & 1 & 0 & 0 \\
\hline Total & 519 & 401 & 214 & 182 \\
\hline
\end{tabular}

Sources: Choice database. 
As of June 2018, there are 519 enterprises of the Pearl River Delta listed in China's A-share market. In 2017, 519 listed companies invested 55.78 billion yuan in R\&D expenditure, accounting for $1.06 \%$ of gross trading income. The original value of patent technology listed companies was 19.91 billion yuan, accounting for 34.09\% of the R\&D expenditure in that year.

According to the urban distribution of listed companies, there are 280 listed companies in Shenzhen, accounting for 53.9\% of listed companies in the Pearl River Delta of China; 98 listed companies in Guangzhou, accounting for $18.88 \%$; and then the order is Foshan, Zhuhai, Dongguan, Zhongshan, Jiangmen, Huizhou and Zhaoqing. Of all listed companies, 401 listed companies listed R\&D expenditure, 214 listed companies listed the original value of patented technology, 182 listed companies listed both R\&D expenditure and the original value of patented technology. (see Table 1)

According to the industry distribution of listed companies, there are 337 listed companies from Manufacturing industry, accounting for 64.9\%; 45 listed companies from Information Transmission, Software and Information Technology industry, accounting for 8.7\%; and then the order is the Real Estate, Construction, Transport, Storage and Post, Wholesale and Retail Trades, and Leasing and Business Services industry. (see Table 2)

\subsection{Empirical Analysis}

\subsubsection{Variable Selection and Data Source}

The selection and definition of variables and data sources are shown in Table 3.

Table 3 The Selection of Variables and Data Sources

\begin{tabular}{|c|c|c|}
\hline Variable & Definition of Variable & Data source \\
\hline $\mathrm{RD}$ & R\&D expenditure & \multirow{3}{*}{ Choice database } \\
\hline Patent & $\begin{array}{l}\text { The original value of patent } \\
\text { technology }\end{array}$ & \\
\hline Income & Gross trading income & \\
\hline Industry1 & $\begin{array}{l}\text { Dummy variable } \\
=1, \text { if Manufacturing } \\
=0 \text {, if others }\end{array}$ & \\
\hline Industry2 & $\begin{array}{l}\text { Dummy variable } \\
=1 \text {, if Information Transmission, } \\
\text { Software and Information } \\
\text { Technology } \\
=0 \text {, if others }\end{array}$ & \\
\hline Industry3 & $\begin{array}{l}\text { Dummy variable } \\
=1, \quad \text { if Real Estate } \\
=0, \text { if others }\end{array}$ & \\
\hline City1 & $\begin{array}{l}\text { Dummy variable } \\
=1 \text {, if Shenzhen } \\
=0 \text {, if others }\end{array}$ & \\
\hline City2 & $\begin{array}{l}\text { Dummy variable } \\
=1, \text { if Guangzhou } \\
=0 \text {, if others }\end{array}$ & \\
\hline
\end{tabular}

\subsubsection{Model Establishment}

In the following of RD model and Patent model, we use the OLS to estimate the models, but in the two models, the R\&D expenditure and the original value of patent technology are the dependent variables, if some observations are not observed, observations of Listed companies are "truncated". That is the problem of selective samples. Heckman (1974) first discovered and proposed the problem of "selective samples". In this paper, Tobit model is used to modify the problem of selective samples.

Suppose that an observation is not observed whenever the dependent variable falls below one 
threshold, or exceeds a second threshold.

The general two-limit truncated regression model may be written as:

$$
y_{i}^{*}=x_{i}^{\prime} \beta+\sigma \varepsilon_{i}
$$

Where $\mathrm{y}_{i}=y_{i}^{*}$ is only observed if: $\mathrm{C}_{1}<y_{i}^{*}<\mathrm{C}_{2}$

The log likelihood function associated with these data is given by:

$$
\mathrm{l}(\beta, \sigma)=\sum_{i=1}^{N} \log f\left(\left(y_{i}^{*}-x_{i}^{\prime} \beta\right) / \sigma\right) \cdot 1\left(C_{1}<y_{i}^{*}<C_{2}\right)-\sum_{i=1}^{N} \log \left(F\left(\frac{\left(c_{2}-x_{i}^{\prime} \beta\right)}{\sigma}\right)-F\left(\frac{\left(c_{1}-x_{i}^{\prime} \beta\right)}{\sigma}\right)\right)
$$

The likelihood function is maximized with respect to $\beta$ and $\sigma$, using standard iterative methods.

\subsubsection{RD model}

Firstly, a multivariate linear regression model (3) for R\&D expenditure of different industries is established, and the OLS and ML (The Truncated Regression or Tobit Model) are used to estimate the RD model respectively. The results are shown in Table 4.

$$
R D_{i}=\alpha_{0}+\alpha_{1} \text { Income }_{i}+\alpha_{2} \text { industry }_{i}+\alpha_{3} \text { industry }_{i}+\alpha_{4} \text { industry }_{i}+\varepsilon_{i}
$$

Table 4 Regression Results of RD model with Different Industry

\begin{tabular}{|c|c|c|c|c|c|c|}
\hline \multirow{2}{*}{ Variable } & \multicolumn{3}{|c|}{ OLS Regression Model } & \multicolumn{3}{c|}{$\begin{array}{c}\text { ML Regression Model } \\
\text { (The Truncated Regression or Tobit } \\
\text { model) }\end{array}$} \\
\cline { 2 - 6 } & Coeff. & t-Statistic & Prob. & Coeff. & t-Statistic & Prob. \\
\hline Constant & $1.78 \mathrm{E}+08$ & 4.8299 & $0.0000^{*}$ & $-8.89 \mathrm{E}+08$ & -4.5837 & $0.0000^{*}$ \\
\hline Income & 0.002574 & 7.2704 & $0.0000^{*}$ & 0.0025668 & 20.3299 & $0.0000^{*}$ \\
\hline Industry1 & $-1.29 \mathrm{E}+08$ & -3.2820 & $0.0011^{*}$ & $-9.51 \mathrm{E}+08$ & -4.6137 & $0.0000^{*}$ \\
\hline Industry2 & $-1.84 \mathrm{E}+08$ & -2.7006 & $0.0072^{*}$ & $-2.09 \mathrm{E}+09$ & -3.6347 & $0.0003^{*}$ \\
\hline Industry3 & $2.03 \mathrm{E}+08$ & 2.3602 & $0.0186^{*}$ & $7.47 \mathrm{E}+08$ & 3.7319 & $0.0002^{*}$ \\
\hline$R^{2}$ & 0.1362 & & & & & \\
\hline
\end{tabular}

Note: * indicates statistical significance at a 5\% significance level.

From the regression results, the gross trading income has a significant impact on $\mathrm{R} \& \mathrm{D}$ expenditure, and industry variables are significant, proving that R\&D expenditure will vary with different industry. The gross trading income of Manufacturing, Information Transmission, Software and Information Technology industries have a negative impact on R\&D investment in the sample. Manufacturing and Information Transmission, Software and Information Technology industries have less R\&D expenditure than other industries, and Real Estate industry has more R\&D investment than other industries. The conclusions of the two models are consistent.

Secondly, a multivariate linear regression model (4) for R\&D expenditure of different city is established, and the OLS and ML are used to estimate the RD model respectively. The results are shown in Table 5.

$$
R D_{i}=\beta_{0}+\beta_{1} \text { Income }_{i}+\beta_{2} \text { City }_{i}+\beta_{3} \text { City }_{i}+\varepsilon_{i}
$$

\begin{tabular}{|c|c|c|c|c|c|c|}
\hline & \multicolumn{3}{|c|}{ OLS Regression Model } & \multicolumn{3}{|c|}{$\begin{array}{c}\text { Truncated Regression Model } \\
\text { (Tobit model) }\end{array}$} \\
\hline Variable & Coeff. & t-Statistic & Prob. & Coeff. & t-Statistic & Prob. \\
\hline Constant & 40050720 & 1.1922 & 0.2337 & $-2.64 \mathrm{E}+09$ & -6.5518 & $0.0000^{*}$ \\
\hline Income & 0.002504 & 6.9006 & $0.0000 *$ & 0.002785 & 19.7212 & $0.0000 *$ \\
\hline City1 & 72499788 & 1.9074 & 0.0570 & $1.43 \mathrm{E}+09$ & 4.7134 & $0.0000^{*}$ \\
\hline City2 & -32513927 & -0.7085 & 0.4791 & $-5.33 E+08$ & $-5.33 E+08$ & 0.1301 \\
\hline$R^{2}$ & 0.0977 & & & & & \\
\hline
\end{tabular}

Table 5 Regression Results of RD model with Different City

Note: * indicates statistical significance at a 5\% significance level. 
From the regression results, the gross trading income still has a significant impact on R\&D expenditure. In addition, the City1 variable is positive and significant, which proves that Shenzhen does have an innovative atmosphere of $R \& D$. The $R \& D$ level of Listed Companies in Shenzhen is higher than that of other cities. However, City2 variable is negative and not significant, indicating that the effect of technological innovation agglomeration in Guangzhou is not obvious, and the R\&D expenditure level of Listed Companies in Guangzhou is lower than that of other cities. The conclusions of the two models are consistent.

\subsubsection{Patent model}

From 519 listed companies, the company that has no R\&D expenditure has left 401 . Of the 401 firms with R\&D expenditure, 182 converted $R \& D$ expenditure into patents technology. So in the OLS model, we use 401 sample data for regression, and Truncated Regression Model has 182 samples.

Firstly, a multivariate linear regression model (5) for the original value of patent technology of different industries is established, and the OLS and ML are used to estimate the Patent model respectively. The results are shown in Table 6.

$$
\text { Patent }_{i}=\alpha_{0}+\alpha_{1} R D_{i}+\alpha_{2} \text { industry }_{i}+\alpha_{3} \text { industry }_{i}+\alpha_{4} \text { industry }_{i}+\varepsilon_{i}
$$

Table 6 Regression Results of Patent model with Different Industry

\begin{tabular}{|c|c|c|c|c|c|c|}
\hline & \multicolumn{3}{|c|}{ OLS Regression Model } & \multicolumn{3}{c|}{$\begin{array}{c}\text { Truncated Regression Model } \\
\text { (Tobit model) }\end{array}$} \\
\hline Variable & Coeff. & t-Statistic & Prob. & Coeff. & t-Statistic & Prob. \\
\hline Constant & -2736160 & -0.0490 & 0.9610 & $-1.24 \mathrm{E}+09$ & -5.7003 & $0.0000^{*}$ \\
\hline RD & 0.3843 & 8.5761 & $0.0000^{*}$ & 2.481950 & 18.2515 & $0.0000^{*}$ \\
\hline Industry1 & -11433299 & -0.1873 & 0.8516 & $-9.81 \mathrm{E}+08$ & -2.7663 & $0.0057^{*}$ \\
\hline Industry2 & -20936137 & -0.2420 & 0.8089 & - & - & \\
\hline Industry3 & -2068480 & -0.0106 & 0.9915 & - & - & \\
\hline$R^{2}$ & 0.1577 & & & & & \\
\hline
\end{tabular}

Note: * indicates statistical significance at a 5\% significance level.

From the regression results, R\&D expenditure has a significant impact on patent technology. But the industry variables are not significant. Considering the Truncated Selected Sample, R\&D still has a significant impact on patented technology, and the Industry 1 variable is negative and significant, which proves that manufacturing industry has the agglomeration effect of patented technology, but the efficiency of $R \& D$ transformation into patented technology is not high in manufacturing industry.

Secondly, a multivariate linear regression model (6) for the original value of patent technology of different cities is established, and the OLS and ML are used to estimate the Patent model respectively. The results are shown in Table7.

$$
\text { Patent }_{i}=\beta_{0}+\beta_{1} R D_{i}+\beta_{2} \text { City }_{i}+\beta_{3} \text { City }_{i}+\varepsilon_{i}
$$

Table 7 Regression Results of Patent model with Different City

\begin{tabular}{|c|c|c|c|c|c|c|}
\hline & \multicolumn{3}{|c|}{ OLS Regression Model } & \multicolumn{3}{c|}{$\begin{array}{c}\text { Truncated Regression Model } \\
\text { (Tobit model) }\end{array}$} \\
\hline Variable & Coeff. & t-Statistic & Prob. & Coeff. & t-Statistic & Prob. \\
\hline Constant & -23708066 & -0.6145 & 0.5393 & $-1.39 \mathrm{E}+09$ & -8.6807 & $0.0000^{*}$ \\
\hline RD & 0.382273 & 8.5779 & $0.0000^{*}$ & 2.2727 & 28.5711 & $0.0000^{*}$ \\
\hline City1 & 21785537 & 0.4890 & 0.6251 & $-4.44 \mathrm{E}+08$ & -2.2632 & $0.0236^{*}$ \\
\hline City2 & -15067415 & -0.2745 & 0.7840 & $-2.76 \mathrm{E}+08$ & -1.1139 & 0.2653 \\
\hline$R^{2}$ & 0.1585 & & & & & \\
\hline
\end{tabular}

Note: * indicates statistical significance at a 5\% significance level.

From the regression results, $R \& D$ expenditure has a significant impact on patent technology. But in the OLS model, the city variable is not significant. Considering Truncated selected Sample, the 
city 1 variable is negative and significant, which proves that Shenzhen has the agglomeration effect of patented technology, but the transformation efficiency of Shenzhen R\&D into patented technology is not high.

\subsubsection{Income model}

In order to prove whether the patent technology is higher, will it increase the gross trading income of listed companies? We selected 401 samples and 182 samples respectively to use OLS method for regression. Because the industry 3 (real estate industry) listed companies have no data of patented technology, so the industry model only joined the first two industries.

Firstly, a multivariate linear regression model (7) for gross trading income of different industries is established, and the OLS and ML are used to estimate the Patent model respectively. The results are shown in Table 8.

$$
\text { Income }_{i}=\alpha_{0}+\alpha_{1} \text { Patent }_{i}+\alpha_{2} \text { industry }_{i}+\alpha_{3} \text { industry }_{i}+\varepsilon_{i}
$$

Table 8 Regression Results of Income model with Different Industry

\begin{tabular}{|c|c|c|c|c|c|c|}
\hline \multirow{2}{*}{ Variable } & \multicolumn{3}{|c|}{ 401sample } & \multicolumn{3}{c|}{ 182 sample } \\
\cline { 2 - 6 } & Coeff. & t-Statistic & Prob. & Coeff. & t-Statistic & Prob. \\
\hline Constant & $8.46 \mathrm{E}+09$ & 3.3754 & $0.0008^{*}$ & $6.95 \mathrm{E}+09$ & 5.0342 & $0.0000^{*}$ \\
\hline Patent & 11.5729 & 5.3528 & $0.0000^{*}$ & 11.84497 & 16.4975 & $0.0000^{*}$ \\
\hline Industry1 & $-3.89 \mathrm{E}+09$ & -1.4141 & 0.1581 & $-3.82 \mathrm{E}+09$ & -2.5854 & $0.0105^{*}$ \\
\hline Industry2 & $-7.24 \mathrm{E}+09$ & $3.98 \mathrm{E}+09$ & 0.070 & $-5.18 \mathrm{E}+09$ & -2.2295 & $0.0270^{*}$ \\
\hline$R^{2}$ & 0.1577 & & & 0.6099 & & \\
\hline
\end{tabular}

Note: * indicates statistical significance at a 5\% significance level.

From the regression results, patent technology has a significant effect on the gross trading income in the two models. However, in the 401 sample, the industry variable is not significant, while in the 182 sample, the industry variable is significant, but it is a negative impact, which shows that in manufacturing and information transmission, software and information technology industries, the ability of listed companies to convert patented technology into the gross trading income is not strong.

Secondly, a multivariate linear regression model (8) for gross trading income of different cities is established, and the OLS and ML are used to estimate the Patent model respectively. The results are shown in Table 9.

$$
\text { Income }_{i}=\beta_{0}+\beta_{1} \text { Patent }_{i}+\beta_{2} \text { City }_{i}+\beta_{3} \text { City }_{i}+\varepsilon_{i}
$$

Table 9 Regression Results of Income model with Different City

\begin{tabular}{|c|c|c|c|c|c|c|}
\hline \multirow{2}{*}{ Variable } & \multicolumn{3}{|c|}{ 401sample } & \multicolumn{3}{c|}{ 182 sample } \\
\cline { 2 - 6 } & Coeff. & t-Statistic & Prob. & Coeff. & t-Statistic & Prob. \\
\hline Constant & $3.10 \mathrm{E}+09$ & 1.7230 & 0.0857 & $2.62 \mathrm{E}+09$ & 2.8896 & $0.0043^{*}$ \\
\hline Patent & 11.45756 & 2.1691 & $0.0000^{*}$ & 11.90071 & 16.1516 & $0.0000^{*}$ \\
\hline City1 & $2.47 \mathrm{E}+09$ & 1.1799 & 0.2387 & $9.43 \mathrm{E}+08$ & 0.8874 & 0.3761 \\
\hline City2 & $1.07 \mathrm{E}+09$ & 0.4146 & 0.6786 & $1.77 \mathrm{E}+09$ & 1.2735 & 0.2045 \\
\hline$R^{2}$ & 0.0698 & & & 0.5975 & & \\
\hline
\end{tabular}

Note: * indicates statistical significance at a 5\% significance level.

From the regression results, Patent technology has a significant impact on the gross trading income in the two models, and the city variables have no significant impact.

\section{Conclusion}

This paper chooses the 519 enterprises of the Pearl River Delta listed in China's A-share market and establishes a multivariate linear regression model with the financial data of 2017. Considering the problem of selective samples, OLS and ML methods are used to analyse the general model and Truncated Regression model respectively. The results show that (1) gross trading income has a significant and positive impact on $R \& D$ investment. The positive influence of $R \& D$ in 
manufacturing and Information Transmission, Software and Information Technology industries are higher than that in other industries. The R\&D level of Listed Companies in Shenzhen is higher than that in other cities. (2) The manufacturing industry has the industrial agglomeration effect of patented technology, but the transformation efficiency of R\&D into patented technology is not high in the manufacturing industry. Shenzhen has the urban agglomeration effect of patented technology, but the transformation efficiency of Shenzhen R\&D into patented technology is not high. (3) The increase of patents helps to increase gross trading income, and the impact of industrial agglomeration of patents is significant, but the urban agglomeration effect of patents is not significant.

\section{References}

[1] Heckman, J. (1974). Shadow prices, market wages, and labor supply. Econometrica: journal of the econometric society, 679-694.

[2] The Chinese State Council. (2012). The Opinions on Deepening the Reform of the Scientific and Technological System and Accelerating the Construction of the National Innovation System.

[3] The Chinese State Council. (2015). Plan for Deepening the Reform and Implementation of the Scientific and Technological System.

[4] The Chinese State Council. (2016). The National Innovation Driven Development Strategy Outline.

[5] EViews 9. Users Guide. 